Prof. Ian Glenn

Research Fellow,

Department of

Communication Science,

University of the

Free State

(GlennIE@ufs.ac.za)

DOI: https://dx.doi. org/10.18820/24150525/

Comm.v22.1

ISSN 2415-0525 (Online)

Communitas 2017 22: 1-15

(c) UFS

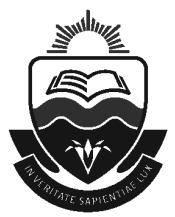

\section{OBAMA AND LIBERAL AFRO-PESSIMISM}

\section{ABSTRACT}

This article ${ }^{1}$ disputes academic accounts of Afro-pessimism, which see it as a product of ideological or discursive bias in the viewer, or as a crude generalisation across very different countries and cultures by examining the context for and major themes of Afro-pessimism after 1994. In particular, it shows that modern Afro-pessimism is largely a product of liberal concerns and liberal media. It demonstrates the salience of these themes by showing how they permeate and influence former US President Barack Obama's African outlook by a close reference to his speech to the Ghanaian parliament in 2009 and suggests that they may provide the context for the views of current US President Donald Trump.

Keywords: Afro-pessimism; Afro-optimism; Western liberal orthodoxy; speech; Barack Obama; Donald Trump; rhetoric; African Union; rhetorical criticism

\section{INTRODUCTION}

How fair are Western media about Africa? Are they biased Afro-pessimists, as many academic critics suggest (De B'béri \& Louw 2011; Nothias 2012; Nothias 2015), or are negative portrayals simply based on reality? After all, on objective measures such as life expectancy, income and access to modern amenities, Africa as a whole ranks far behind the developed world. Even on more subjective measurements such as the Happiness Index, inhabitants of African countries, on average, are far less content with their lives than citizens in the rest of the world (Helliwell et al. 2017).

At this point the debate often turns, not to the merits of the critique of Africa or its substance, but into an academic exercise of discourse analysis and psychological "explanations". The critics, it is argued, resort to old racial stereotypes of darkest Africa, aggregate the experience of many different countries into a totality, view selectively and negatively, compare Africa unfairly to Europe and make unfair and pessimistic predictions. A recent dissertation applies Van Dijk's claim that anybody who denies that their negative portrayal is driven by racism is suffering from intention denial and justification (Van Dijk 1992, in Nothias 2015: 229). 
There is something unsatisfactory about a line of argument that ends up suggesting that any critique of post-independence Africa is illegitimate. Further, those arguing that Western media are too Afro-pessimistic often fail to examine the history of Afropessimism from René Dumont and Achebe and others onwards to see how the earlier Afro-pessimism differs from the later one and to distinguish what the major features of more recent critiques are. When it becomes clear that the critique of Africa over the past 25 years or so, in spite of many continuities, has changed emphasis from criticisms in the 1960s in the first post-independence phase, it becomes more difficult to see it as a mere product of stereotyping. More critically, the attempts to delegitimise any critique of Africa fail to observe the crucial feature of what we can call the second wave of post-1994 Afro-pessimism: that it is largely the product of left-wing and liberal media organisations and journalists.

There is another, more compelling, reason to reject all criticisms of Africa as a product of the observer's bias and racism. To do this is to neglect the real force of liberal orthodoxies about Africa and their impact on politicians, politics and policies. Those arguing that all criticisms of Africa are unfounded on the one hand, or those arguing that former US President Barack Obama was not nearly as sympathetic to Africa while president as they had expected, miss the crucial connection: Obama's outlook was shaped by powerful criticisms of and concerns about Africa (Lyman \& Robinette 2009; Washington 2010; Carson 2013; Van de Walle 2015).

After a further discussion of Afro-pessimism, this article turns to Obama's major African speech to the Ghanaian parliament in 2009 as the best summary of the major tropes of modern liberal Afro-pessimism. In the final section, the article moves briefly to consider Obama's second major African speech to the African Union in 2016 and to what the context of liberal Afro-pessimism should predict for the African views of current US President Donald Trump.

\section{AFRO-PESSIMISMS AND THEIR CONTEXT}

The spirit of much of this modern liberal Afro-pessimistic writing recalls that of Dumont who, writing in 1962 after the first wave of African independence, opens L'Afrique noire est mal partie (False start in Africa) with a sense of physical angst - his pen trembling as he starts to write material that may justify the white colonists or irritate blacks (Dumont et al. 1969; Dumont 1973).

Many of the issues and themes that concern liberal Afro-pessimists are not new. The critical novels of writers such as Achebe, Soyinka, Ngugi and Beti, or the social analyses of Andreski, Achebe, Dumont and Mazrui have kept much of their cogency (Andreski 1968; Achebe 1983; Mazrui 1980). Nonetheless, continuities should not mask the extent to which new themes occur. These themes, old and new, provide a framework, the mainstream Western cognitive map, for understanding how Africa appears to media in the developed world. They help explain why a liberal US President like Obama sees Africa the way he does.

The new Afro-pessimism arose in a particular global political context. After the fall of the Berlin Wall and the end of the Cold War, white rule in South Africa ended peacefully 
with a political transition that gave hope. This allowed an examination of Africa not dominated by the issue of apartheid and the scandal of white racist rule. Given that super-power rivalry for African resources and African allies seemed to be over, states could be judged more pragmatically, self-interestedly and critically.

As Schraeder and Endless (1998: 33) note in a study of increasingly pessimistic news coverage of Africa in The New York Times during the 1990s:

The most noteworthy trend was the media's rising focus on sociocultural issues in the postapartheid era. Feature articles in this category rose from 14 percent of total coverage in 1990 to 23 percent in 1995. These articles focused on a variety of transnational trends - illegal African immigration, health issues posed by the AIDS and Ebola viruses, and drug trafficking from West and Southern Africa - considered to pose significant threats to the domestic well-being of the United States.

This study notes how dramatically coverage of Africa switched from coverage of race to coverage of ethnicity, but, if anything, it underestimates the full extent of the change as it does not take into account the ongoing effects of the Rwandan massacres of 1994 that were felt throughout the decade. After 9/11, the negative perceptions of Africa or African states perceived to be too sympathetic to Muslim extremism would heighten the negative images associated with Somalia in the United States.

The outbreak of piracy in the coasts off Somalia, Boko Haram, the activities of Joseph Kony, accusations of genocide in Sudan and political turmoil in previously stable states like Kenya and the Ivory Coast have all been factors in leading to a generally pessimistic view in Western media. But, more than half a century after Dumont wrote, the tone was less apologetic. In almost all of Africa, there are no colonists left worth worrying about and patience has worn thin after half a century of further failure while others have succeeded.

Nor was this pessimism only in print journalism. Since the end of white rule in South Africa in the period between 1990 and 1994, new discourses and concerns came to dominate international perceptions of Africa, in television news, cinema (like Hotel Rwanda, Last King of Scotland, Blood Diamonds and The Interpreter) (Evans \& Glenn 2010), travel writing like Paul Theroux's Dark Star Safari (Theroux 2002), or novels like J.M. Coetzee's Disgrace (Coetzee 1999).

What is surprising in these attacks is that they emanated, whether in Europe or in North America or even in Africa or South Africa, not mainly from traditional right-wing sources, or voices of capitalism. They came, and continue to come, from what one might consider liberal writers and the bastions of left or centre-left liberalism: in France from Le Monde and Le Monde Diplomatique and Le Nouvel Observateur, in Britain from The Guardian or The Observer or the BBC, and in the USA from The Washington Post or The New York Times or Vanity Fair or The New Yorker, or from what many Americans regard as the liberal source itself: Hollywood. In South Africa, the toughest critiques of the new ANC government have come from people with impeccable struggle and anti-apartheid credentials: from André P. Brink and Pieter-Dirk Uys and cartoonist Zapiro, and disillusioned ex-ANC figures like Pregs Govender and Andrew Feinstein (Feinstein 2007; Govender 2007), and, increasingly from African leaders such as 
Desmond Tutu, ANC struggle stalwarts like Ahmed Kathrada, or the breakaway Economic Freedom Fighters led by Julius Malema.

Many other writers from nominally liberal papers, particularly Africa correspondents like Steven Smith, a Le Monde correspondent, or Rory Carroll, a Guardian correspondent, like African-American Washington Post correspondent Keith Richburg before them, broke from the general orthodox liberal or left-wing stance of their newspapers to write more politically unsettling pieces (Smith 2003; Carroll 2006; Richburg 1997). In Smith's Negrologie: pourquoi l'Afrique meurt (literally Negrology, why Africa is dying), he takes on what he sees as the African leaders' typical quest for a historical status whether in Négritude or, in the case of former South African President Thabo Mbeki, the African Renaissance (Smith 2003). In his analysis, this historical obsession is at once barrier to and mask for poor governance.

After the Cold War, Africa received a searching new examination as the international media no longer felt obliged to defend African states. In this shift, liberal or left-wing media became new critical voices as they remained more engaged with Africa than right-wing publications, which had in many cases written off independent Africa as a lost cause.

The characteristic tones of this new Afro-pessimism, marked by disappointment and disillusion, are anger, tough love or cool dispassion. In the film The Interpreter, by director Sydney Pollack, there is a telling exchange when the American Secret Service officer, played by Sean Penn, asks the white African-born United Nations interpreter, played by Nicole Kidman, what her feeling is about Zuwanie, the liberator-turneddictator of her home country - a figure who seems to be modelled on Robert Mugabe and Hastings Banda. She replies, "Disappointment". "It's a lover's word," he accuses, and that exchange helps explain much of the emotional tone of liberal Afro-pessimism.

The concerns stem from dismay at events in the history of independent African states. Liberal Afro-pessimism is well-informed, disappointed, rather than being the product of any kind of simple racial prejudice. It is the view of Africa of a Desmond Tutu or Barack Obama, not of somebody indifferent.

\section{OBAMA'S CRITIQUE}

Barack Obama's speech to the Ghanaian parliament in July 2009 was centrally illuminating because that speech confirms that the Obama administration shared the concerns and views of this new Afro-pessimism and factored them into its policy (Obama 2009). Obama's speech was relatively short, but packed with observation and pointed critique. In isolating its major themes, a summary of his statement or the relevant quote from his speech is followed by a brief elaboration to explain its provenance and force.

\section{Tribalism, nepotism, corruption and kleptocracy}

In my father's life, it was partly tribalism and patronage and nepotism in an independent Kenya that for a long stretch derailed his career, and we know that this kind of corruption is still a daily fact of life for far too many ... No country is going 
to create wealth if its leaders exploit the economy to enrich themselves, or police can be bought off by drug traffickers. No business wants to invest in a place where the government skims 20 percent off the top, or the head of the Port Authority is corrupt. [...] I have directed my Administration to give greater attention to corruption in our Human Rights report. People everywhere should have the right to start a business or get an education without paying a bribe. We have a responsibility to support those who act responsibly and to isolate those who don't, and that is exactly what America will do (Obama 2009).

One fairly constant critique of African states from the beginnings of independence has been that of corruption and the tendency of leaders and officials to use their office for self-enrichment rather than the public good. Early novels, like Achebe's 1966 Man of the people, recorded the loss of idealism in the face of ethnic mobilisation, election rigging and military take-overs, while Andreski controversially identified the notion of a "kleptocracy" as a form of African government (Achebe 1988; Andreski 1968). Other works, like De Sardan's analysis of the "moral economy of corruption" or Bayart's work on the "politics of the stomach", gave more detail of how power worked as a way of channelling public wealth and resources to powerful individuals without challenging the generally pessimistic tone (De Sardan 1999; Bayart 1993).

While anthropologists might see corruption as a modern form of clientelism or a "big man" tradition, journalists could point quite reasonably to the fact that no politicians or ideologues came to any overt defence of this practice. When politicians themselves were entering ritual denunciations of (usually other politicians') political corruption, it was difficult to shrug this off as business as usual. For Obama, the issue of corruption was central to his analysis and he indicated that the US administration would include corruption as a factor in its Human Rights reports.

\section{Pathology of leadership}

Africa doesn't need strongmen, it needs strong institutions (Obama 2009).

A central recurring motif of Afro-pessimism has been the failure of electoral systems and democratic institutions. After the coming of democratic government to South Africa, there was, for a while, a sense of increasing democratisation, of a rise of new young idealistic leaders and of reasons for belief in an African Renaissance and for Afrooptimism (Gordon \& Wolpe 1998). Once again, South Africa was seen as exemplary with Nelson Mandela's retirement after only one term of office seen as a reaction to the "big man" syndrome and the tendency to dictatorship elsewhere in Africa.

While some critics rejected the Afro-optimism at the time (Rieff 1998), events in the twenty-first century have led to a renewed interest in what one might call the pathology of power. Museveni of Uganda complained rightly about the 30 years lost to the sergeants, but he still clings to power. In Kenya, a disputed election and postelection violence made another of the "advanced states" seem to be as shaky in its democratic robustness as the Ivory Coast had proved to be before it. And the support of the South African government for Zimbabwean President Robert Mugabe when he refused to accept the 2008 election results in Zimbabwe was, for many observers, another example of African contempt for the electoral process. 
The complaint about leaders clinging to power and of their undermining of institutions was central to Obama's comments in both speeches.

\section{Economy and technology}

But despite the progress that has been made - and there has been considerable progress in many parts of Africa - we also know that much of that promise has yet to be fulfilled. Countries like Kenya had a per capita economy larger than South Korea's when I was born. They have badly been outpaced. Disease and conflict have ravaged parts of the African continent (Obama 2009).

One consequence of the post-Cold War era and the intellectual and political realignments that followed was that societies and nations were judged on the basis of economic performance and on how they reacted to the new global economy and forces controlling and shaping it. Whether from economic and technological historians like Manuel Castells, formerly a 1968 radical, who famously or infamously judged the dangers of Africa falling into or simply being one of the "black holes of informational capitalism" or popularisers like The New York Times columnist Thomas Friedman, the judgment on Africa was damning (Castells 1998; Friedman 2005). African states had started off with more apparent natural advantages and wealth than countries like India or China, but had fallen behind in the global race to prosperity and technological advancement.

These critiques also serve as a rebuttal to the argument of Jared Diamond that environmental rather than cultural factors determine Africa's fate (Diamond 1998). A leitmotif from the developed world, recurring in a host of writing, is that if the eastern countries can join in and benefit from globalisation, why can African countries not do the same? For Friedman, countries not benefiting from the global economy were simply not trying hard enough, not willing to benefit from the win-win possibilities of global trade. To try to resist the force of a real-time world was simply obtuse. If the criterion of judgment of a country or a continent in a post-Cold War era became economic rather than ideological, Africa had to be judged as persistently failing and journalists could outline how its governments, instead of being champions of economic performance, were all too often hindrances to it.

\section{The war on terror and the criminal state}

When there is genocide in Darfur or terrorists in Somalia, these are not simply African problems - they are global security challenges, and they demand a global response (Obama 2009).

A state that is internally kleptocratic may move quite rapidly towards becoming something worse, more threatening in the new global war on terror. So, whether it was Samuel Huntington, looking at the coming clash of civilizations, or Robert D. Kaplan, a reporter whose The Coming Anarchy predicted a grim future and role for African nation-states, those warning about the possible threats from Africa got a hearing across the normal political divides (Huntington 1996; Kaplan 2000). Here is Kaplan, in an influential 1994 Atlantic piece (Kaplan 1994, reprinted in his The Coming Anarchy): 
West Africa is becoming the symbol of worldwide demographic, environmental and societal stress, in which criminal anarchy emerges as the real 'strategic' danger. Disease, over-population, unprovoked crime, scarcity of resources, refugee migrations, the increasing erosion of nation-states and international borders, and the empowerment of private armies, security firms and international drug cartels are now most tellingly demonstrated through a West African prism (Kaplan 2000: 7).

In addition, the Realpolitik of a Huntington or Kaplan also suggested that Africa was, in whole or part, a hostile force to American interests - a view that increased in force after disastrous American forays into Somalia and the discovery that Osama bin Laden had been harboured in Africa. After the moral outrage over apartheid settled, a new look at Africa did not produce much that Americans, in particular, wanted to see. And the lawlessness and anarchy was not only confined to West Africa as repeated acts of piracy by Somalis off the Horn of Africa revealed and continue to reveal.

Obama's observation was in time strengthened by the realisation that the poaching of ivory and rhino horn in East Africa aided Al-Qaeda financing, while the recent discovery that North Korean diplomats have been involved in rhino horn smuggling in South Africa also suggests that Africa can be seen as a weak link in anti-terrorism initiatives. In Obama's speech to the African Union in 2015 he explicitly mentioned the dangers of wildlife trafficking (Obama 2015).

\section{The resource curse hypothesis}

So in Ghana, for instance, oil brings great opportunities, and you have been very responsible in preparing for new revenue. But as so many Ghanaians know, oil cannot simply become the new cocoa. From South Korea to Singapore, history shows that countries thrive when they invest in their people and in their infrastructure ... For far too many Africans, conflict is a part of life, as constant as the sun. There are wars over land and wars over resources (Obama 2009).

Another major theme about developing nations and their problems, in American social analysis in particular, was what came to be known as the resource curse hypothesis (Auty 1993; Friedman 2006; Stiglitz 2006; Le Billon \& International Institute for Strategic Studies 2005; Humphreys et al. 2007; Dunning 2005). In brief, this held that rich mineral resources lead to endless struggles to control the state which could enrich those holding power and dispensing mineral rights, rather than leading to a government committed to creating wealth through educated citizens.

Most of the analysis of the "resource curse" came, in the first instance, from concern with developments in the oil-rich Middle East. In the case of Africa, critics argued that having rights to resources as the spoils of civil war not only encourages corrupt and kleptocratic government but also undermines effective, idealistic opposition because opponents tend to turn to violence in an attempt to seize control of mineral rights (Weinstein 2005; Collier \& Hoeffler 2005; Herbst 2000).

While some recent research takes issue with some of the more deterministic claims of the resource curse, or sees new ways it develops (Frankel 2010; Moyo 2012), Obama's speech shows his awareness of this issue. This is seen both in a gentle 
warning to Ghanaians that their oil wealth is not the true source of wealth and in his urging of Africa to follow an Asian model of human development.

\title{
Child soldiers
}

\begin{abstract}
But the West is not responsible for the destruction of the Zimbabwean economy over the last decade, or wars in which children are enlisted as combatants ... It is the death sentence of a society to force children to kill in wars (Obama 2009).
\end{abstract}

No single human issue has probably mattered more in perceptions of Africa during the past two decades than the issue of child soldiers (Jensen 1996; Wessells 1998; De Berry 2001; Hick 2001; Fox 2004; Park 2006; Medeiros 2007; Kimmel \& Roby 2007). For Western critics, the treatment of children, particularly kidnapped female children, was a continuing source of concern and outrage: "For example, the UK newspapers The Times and The Sunday Times have published more than 60 articles in the past 5 years with reference to child soldiers, and The New York Times has published more than 100 articles since 1996" (Fox 2004). While Fox looked at The Times, a comparison of coverage in newspapers at what one might call left and right wing, or liberal and conservative ends of the political spectrum in the UK, shows that The Guardian published many more articles about this phenomenon than The Telegraph. This once again shows that liberal media showed greater awareness of, concern about, and, consequently, pessimism about these developments.

Serious academic articles considered the evidence of wide-spread cannibalism, drug usage, belief in the efficacy of magic and charms against bullets, and adulation of charismatic leaders. (Medeiros 2007). It is difficult reading this literature not to feel that Western critics simply could not find adequate ways to react to these events, whether imaginatively, medically or psychologically. Only rarely does a critic seem to grasp the enormity of these events and gauge their repercussions for the human and symbolic landscape, as Achille Mbembe tries to (Mbembe 2002). One of the significant achievements of the film Blood Diamond was to try to confront the psychological and social toll exacted by the capture and use of child soldiers (Zwick 2006).

\section{Rape and sexual violence}

It is the ultimate mark of criminality and cowardice to condemn women to relentless and systematic rape (Obama 2009).

Sexual violence against women and children and even babies became another staple of the international concern with individual rights during this period, particularly in reporting on South Africa and on war-torn areas such as the Democratic Republic of Congo or Darfur (Turshen 2001; Buss 2009; Lefort 2003; Smith 2005a; Smith 2005b).

Former South African President Thabo Mbeki clashed publicly with South African journalist and rape survivor Charlene Smith, accusing her of racism for her characterisation of rape trends in South Africa. Smith subsequently wrote a series of articles for Le Monde Diplomatique, probably the leading organ of left-wing international reporting in France, reporting on how widespread rape in South Africa was (Smith 2005a; Smith 2005b). Her reporting, along with those of concerned women's 
groups, or the version in Coetzee's Disgrace and the reports of rape by the Janjaweed as a weapon of war reached the liberal Western media and remain dominant there.

\section{HIV/Aids}

In Obama's Ghana speech, he refers twice to the treatment of HIVIAids, once referring obliquely to the change in stance in South Africa, the second time referring appreciatively to the "strong efforts of President Bush". Here again we see that Obama sits in the mainstream of Western opinion that saw South African responses, in particular, as inadequate and tardy.

The first major negative portrayal of Mbeki's Aids denialism was written by Samantha Power and appeared in The New Yorker (Power 2003). Power is a Pulitzer Prize winner for a book on modern genocide, A problem from hell: America and the Age of Genocide (Power 2013). She held a prominent position in the Obama campaign and administration, notably as US Ambassador to the United Nations from 2013 to 2017. This connection shows that liberal academic analysis fed through to policy not only as discourse but as personnel choice.

Obama's implicit criticism of Mbeki may have had a personal edge. When Obama, then a junior senator from Illinois, visited South Africa in 2006, he visited the Treatment Action Campaign (TAC) in Cape Town and issued a statement condemning the Minister of Health's stance. Mbeki, apparently stung by the criticism, cancelled a meeting with Obama (Van Vuuren 2008).

\section{Genocide}

When Obama explicitly used the word "genocide" about Darfur, he signalled that he did not accept African defences of events there as simply an internal matter (Scherrer 2002). If child soldiers or the rights of women drew on notions of individual liberal rights to trump any notion of cultural difference or self-determination, genocide was another powerful term and claim that enabled or forced Western media into a critical stance that overrode any claims to African norms or African autonomy. Genocide became a heated issue, particularly after the Rwandan massacres of Tutsis by Hutus in 1994 when the indifference of major international powers and relative media neglect led to considerable soul-searching after the event and to heavy politicisation of the term "genocide".

While Mamdani and others have tried to offer different accounts of events in Rwanda or Darfur (Mamdani 2010), Power's book on genocide and her role as his adviser indicates that Obama used this word deliberately and advisedly. Political struggles to represent government repression as "genocide" were central to what happened in Darfur precisely because "genocide" is the one condition more or less guaranteed to ensure international intervention. That genocide could become the accepted term for events in another African country after Rwanda and again blamed on ethnic rather than racial violence did much to change liberals' optimism about Africa. 


\section{The curse of aid}

For Obama in Ghana, the problems of aid loomed large and his speech articulated several nuances. He indicated the need for assistance to build transformational change; he showed that he was aware of the critique that too much of aid money ends up in the hands of Western aid organisations; he promised to help provide farmers with new methods and technologies that would in time render aid obsolete; and he acknowledged ways in which donor nations have weakened local civil society by recruiting highly trained Africans. All of these comments showed that he had absorbed the complex and painful lessons that the new Afro-pessimism had been discovering about how the path paved with good intentions has not led to the hoped-for improvements (Easterly 2006; Calderisi 2006; Krotz 2007; Whitfield 2009; Glennie 2010).

The idea that aid was not doing any good for Africa was a staple of earlier criticisms sharpened by later critics who came to see it as a more sinister force. For an earlier critic like Bauer, aid was simply an economic illogicality - if a country deserved investment, it did not need aid, while if it could not sustain and justify investment, it was highly unlikely to benefit from aid (Bauer 1957). Large sums of aid money did little to help Africa as they had helped post-war Germany or members of the European community, and earlier critics tended to see this as a sign of a kleptocratic governing class.

In later critiques, aid comes under further attack. For some radical critics, the International Monetary Fund and other international agencies with their structural adjustment and other plans are agents of a neo-liberal economic agenda making disastrous decisions for Africa that have done nothing but harm standards of living. But while this kind of large scale economic "aid" may have come under one form of critique, the do-good aid also came under sharp scrutiny. Now aid is no longer seen merely as inefficient or unlikely to improve things, but as a structural underpinning of corrupt or violent governments. Aid becomes another resource curse, something governments and corrupt officials struggle to control, use and abuse to increase their power. While De Sardan may have been the first to identify this trend, the most powerful version of this critique is that of Dambisa Moyo in her Dead Aid, a work extensively reviewed and commented on in the international media (Moyo 2009). These critiques started influencing government perceptions and policy in the West (Whitfield 2009).

At the level of government aid, the repercussions of perceptions were certainly felt in the period just before Obama's speech. As Reverchon reports, the levels of aid to developing countries dropped between 2006 and 2007: from the United Kingdom by $29 \%$, by $15 \%$ for France, by $30 \%$ for Japan, and $10 \%$ for the USA (Reverchon 2008 ). While one can point to other economic factors involved, it does seem that the rationale for many kinds of aid to Africa has been thoroughly undermined.

\section{OBAMA'S SECOND AFRICAN SPEECH TO THE AFRICAN UNION}

In Obama's second major African speech, that to the African Union in Addis Ababa in 2015 , he returned to several motifs of his earlier speech, but also sounded several new concerns (Obama 2015). His most optimistic note was about the spread of mobile 
technologies in Africa and their possibility, though he also warned about the threats to a continent with so many young people of unemployment and youth dissatisfaction.

Obama also turned to two other major modern American concerns about Africa: the role of China in supplanting Western societies in many countries as the primary investor and benefactor; and the need for Africa to treat women as equal citizens. Though Obama did not mention China specifically, he warned Africa about people whose interest was simply in extracting wealth from the continent. One common observation about China's role in Africa is that it differs from much Western aid in not attaching aid to conditions about human rights or criticisms (Brautigam 2011). Obama tried to present the American view as based on respect for common humanity rather than Western superiority, but his criticisms also seemed much more muted in the second speech.

\section{TRUMP AND THE NEW CRITIQUE OF AFRICA}

Many Africans have been concerned by what the presidency of Donald Trump will mean for US relations with Africa. In his view of Africa, as on much else, Trump presents what seems to be a caricature of conventional right-wing views on his Twitter account. He praises Mandela, but South Africa has, in his view, become crime-ridden after Mandela; aid to Africa would be wasted; investment in African infrastructure was misplaced given the US's own infrastructural needs, and so on. Yet, in many of these cases, there is little in Trump's views that differs sharply from the pessimistic liberal account of Africa.

If there is one area where Trump's rhetoric and views on Africa may differ from Obama's it is on immigration from Africa to the developed world. Obama referred only obliquely to African immigration to the US as showing that the American Dream was open to all. For Trump, as for much of Europe, immigration is a central issue threatening national identity. His travel ban targets two African countries among the six in total: Somalia and Sudan. Given the likelihood that many more young Africans will try to reach Europe and the United States for political and economic reasons in the years ahead, increased tensions seem likely.

\section{CONCLUSION}

Western attitudes towards Africa, particularly as articulated by liberal or left-wing media, grew more pessimistic after 1994. We can locate this shift historically, as happening after the fall of the white regime in South Africa, when the scrutiny of Africa became a more general one. Other major factors that deepened the pessimism included genocide in Rwanda, ongoing ethnic conflict in Darfur, Aids denialism, civil wars and profligate corrupt governments.

As President Obama's Ghana speech showed, we have a well-established Western liberal orthodoxy about Africa with major themes and emphases, an orthodoxy that may have done much to shape his outlook and policy as president. While President Trump's rhetoric is coarser, he does not yet, in most crucial ways, seem to depart that far from the vision of his predecessor. 


\section{ENDNOTES}

1 This work is based on research supported in part by the National Research Foundation of South Africa (grant number 108838).

\section{REFERENCES}

Achebe, C. 1983. The trouble with Nigeria. Enugu, Nigeria: Fourth Dimension.

Achebe, C. 1988. A man of the people. London: Heinemann.

Andreski, S. 1968. The African predicament: A study in the pathology of modernization. London: Michael Joseph.

Auty, R.M. 1993. Sustaining development in mineral economies: The resource curse thesis. London: Routledge.

Bauer, P.T. 1957. Economic analysis and policy in under-developed countries. Cambridge, UK: Cambridge University Press.

Bayart, J-F. 1993. The state in Africa: The politics of the belly. London: Longman.

Brautigam, D. 2011. The dragon's gift: The real story of China in Africa. Oxford: Oxford University Press.

Buss, D.E. 2009. Rethinking 'rape as a weapon of war'. Feminist legal studies 17: 145-163. https://doi.org/10.1007/s10691-009-9118-5

Calderisi, R. 2006. The trouble with Africa: Why foreign aid isn't working. London: Palgrave Macmillan.

Carroll, R. 2006. How I never quite fell for South Africa. The Guardian, August 15.

Carson, J. 2013. The Obama Administration's Africa Policy: The First Four Years, 2009 2013. American Foreign Policy Interests 35: 317-324. https://doi.org/10.1080/1080 3920.2013 .855549

Castells, M. 1998. End of millennium. Malden, MA: Blackwell.

Coetzee, J.M. 1999. Disgrace. London: Secker \& Warburg.

Collier, P. \& Hoeffler, A. 2005. Resource rents, governance, and conflict. Journal of Conflict Resolution 49: 625-633. https://doi.org/10.1177/0022002705277551

De B'béri, B.E. \& Louw, P.E. 2011. Afro-pessimism: A genealogy of discourse. Critical Arts 25: 335-346. https://doi.org/10.1080/02560046.2011.615118

De Berry, J.O. 2001. Child soldiers and the Convention on the Rights of the Child. The ANNALS of the American Academy of Political and Social Science 575: 92-105. https://doi.org/10.1177/000271620157500106

De Sardan, J.P.O. 1999. A moral economy of corruption in Africa? Journal of Modern African Studies 37: 25-52. https://doi.org/10.1017/S0022278X99002992

Diamond, J.M. 1998. Guns, germs and steel: A short history of everybody for the last 13,000 years. New York: Random House.

Dumont, R. 1973. L'Afrique noire est mal partie. Paris: Editions du Seuil.

Dumont, R., Ott, P.N., Balogh, T. \& Hatch, J. 1969. False start in Africa. London: Deutsch. 
Dunning, T. 2005. Resource dependence, economic performance, and political stability. Journal of Conflict Resolution 49: 451-482. https://doi. org/10.1177/0022002705277521

Easterly, W.R. 2006. The white man's burden: Why the West's efforts to aid the rest have done so much ill and so little good. New York: Penguin.

Evans, M. \& Glenn, I. 2010. "TIA - This is Africa": Afro-pessimism in twenty-first century narrative film. Black Camera 2: 14-35. https://doi.org/10.2979/blc.2010.2.1.14

Feinstein, A. 2007. After the party: A personal and political journey inside the ANC. Johannesburg: Jonathan Ball.

Fox, M-J. 2004. Girl soldiers: Human security and gendered insecurity. Security Dialogue 35: 465-479. https://doi.org/10.1177/0967010604049523

Frankel, J.A. 2010. The natural resource curse: A survey. National Bureau of Economic Research. https://doi.org/10.3386/w15836

Friedman, T.L. 2005. The world is flat: A brief history of the twenty-first century. New York: Farrar, Straus and Giroux.

Friedman, T.L. 2006. The first law of petropolitics. Foreign Policy May/June: 28-36.

Glennie, J. 2010. The trouble with aid: Why less could mean more for Africa. London: Zed Books.

Gordon, D.F. \& Wolpe, H. 1998. The other Africa: an end to Afro-pessimism. World Policy Journal 15: 49-59.

Govender, P. 2007. Love and courage: A story of insubordination. Auckland Park, JHB: Jacana.

Helliwell, J., Layard, R. \& Sachs, J. 2017. World Happiness Report 2017. New York: Sustainable Development Solutions Network.

Herbst, J. 2000. Economic incentives, natural resources and conflict in Africa. Journal of African Economies 9: 270-94. https://doi.org/10.1093/jae/9.3.270

Hick, S. 2001. The political economy of war-affected children. The ANNALS of the American Academy of Political and Social Science 575: 106-121. https://doi. org/10.1177/000271620157500107

Humphreys, M., Sachs, J. \& Stiglitz, J.E. 2007. Escaping the resource curse. New York: Columbia University Press.

Huntington, S.P. 1996. The clash of civilizations and the remaking of world order. New York: Simon \& Schuster.

Jensen, J.P. 1996. War-affected societies and war-affected children: What are the long-term consequences? Childhood 3: 415-421. https://doi. org/10.1177/0907568296003003007

Kaplan, R.D. 1994. The coming anarchy. The Atlantic, February: 44-76.

Kaplan, R.D. 2000. The coming anarchy: shattering the dreams of the post Cold War. New York: Random House. 
Kimmel, C.E. \& Roby, J.L. 2007. Institutionalized child abuse: The use of child soldiers. International Social Work 50: 740-54. https://doi.org/10.1177/0020872807081901

Krotz, L. 2007. So much for foreign aid. Maclean's 120: 36-39.

Le Billon, P. \& International Institute for Strategic Studies. 2005. Fuelling war: Natural resources and armed conflict. New York: Routledge for the International Institute for Strategic Studies, London.

Lefort, R. 2003. Congo: l'enfer pour les femmes. Le Nouvel Observateur.

Lyman, P.N. \& Robinette, K.A. 2009. Obama and Africa: Matching expectations with reality. Journal of International Affairs 62(2): 1-18.

Mamdani, M. 2010. Saviors and survivors: Darfur, politics, and the war on terror. New York: Three Rivers Press.

Mazrui, A.A-A. 1980. The African condition, a political diagnosis. London: Heinemann.

Mbembe, A. 2002. African modes of self-writing. Public Culture 14: 239-273. https://doi. org/10.1215/08992363-14-1-239

Medeiros, E. 2007. Integrating mental health into post-conflict rehabilitation: The case of Sierra Leonean and Liberian 'Child Soldiers'. Journal of Health Psychology 12: 498504. https://doi.org/10.1177/1359105307076236

Moyo, D. 2009. Dead aid: Why aid is not working and how there is another way for Africa. London: Penguin.

Moyo, D. 2012. Winner take all: China's race for resources and what it means for us. London: Allen Lane.

Nothias, T. 2012. Definition and scope of Afro-pessimism: Mapping the concept and its usefulness for analysing news media coverage of Africa. Leeds African Studies Bulletin 74: 54-62.

Nothias, T. 2015. Beyond Afro-pessimism? British and French print media discourse on Africa. Unpublished doctoral thesis, University of Leeds.

Obama, B. 2009. Obama Ghana speech: full text. Huffington Post [Online]. Available: http:// www.huffingtonpost.com/2009/07/11/obama-ghana-speech-full-t_n_230009.html [Accessed on 19 July 2009].

Obama, B. 2015. Remarks by President Obama to the people of Africa. July 28 ed. Washington D.C.

Park, A.S.J. 2006. 'Other inhumane acts': Forced marriage, girl soldiers and the Special Court for Sierra Leone. Social Legal Studies 15: 315-337. https://doi. org/10.1177/0964663906066611

Power, S. 2003. The AIDS Rebel. The New Yorker, May 19.

Power, S. 2013. "A problem from hell”: America and the age of genocide. New York: Basic Books.

Reverchon, A. 2008. Le Gange? Plutôt le Zambèze. Le Monde, 16 April.

Richburg, K.B. 1997. Out of America: A black man confronts Africa. New York: Basic Books.

Rieff, D. 1998. In defense of Afro-pessimism. World Policy Journal 15(4): 10-22. 
Scherrer, C.P. 2002. Genocide and crisis in Central Africa: Conflict roots, mass violence, and regional war. Westport, CT: Greenwood.

Schraeder, P.J. \& Endless, B. 1998. The media and Africa: The portrayal of Africa in the New York Times (1955-1995). Issue 81: 29-35.

Smith, C. 2005a. Dans un pays miné par le sida: La jeunesse sud-africaine face aux violences sexuelles. Le Monde Diplomatique, 22-23.

Smith, C. 2005b. Quand le président flatte le machisme. Le Monde Diplomatique, 22.

Smith, S. 2003. Négrologie : Pourquoi l'Afrique meurt. Paris: Calmann-Lévy.

Stiglitz, J.E. 2006. Making globalization work. New York: W.W. Norton.

Theroux, P. 2002. Dark star safari: Overland from Cairo to Cape Town. London: Hamish Hamilton.

Turshen, M. 2001. The political economy of rape: An analysis of systematic rape and sexual abuse of women during armed conflict in Africa. In: Moser, C. \& Clarke, F. (eds). 2001. Victors, perpetrators or actors: Gender, armed conflict and political violence. London: Zed Books.

Van de Walle, N. 2015. Obama and Africa. Foreign Affairs 94(5): 45-54.

Van Dijk, T. 1992. Discourse and the denial of racism. Discourse \& Society 3: 87-118. https://doi.org/10.1177/0957926592003001005

Van Vuuren, M. 2008. SA leaders 'too busy' for Obama. Rapport, 9 November.

Washington, R.E. 2010. Obama and Africa. Race in the Age of Obama. Bingley, UK: Emerald.

Weinstein, J.M. 2005. Resources and the information problem in rebel recruitment. Journal of Conflict Resolution 49: 598-624. https://doi.org/10.1177/0022002705277802

Wessells, M.G. 1998. Children, armed conflict, and peace. Journal of Peace Research 35: 635-646. https://doi.org/10.1177/0022343398035005006

Whitfield, L. 2009. Reframing the aid debate: Why aid isn't working and how it should be changed. Danish Institute for International Studies working paper.

Zwick, E. (dir.) 2006. Blood Diamond. Film. 